\title{
Market and non-market responses to the GFC: Housing Policy in the UK
}

\author{
Kenneth Gibb \\ University of Glasgow
}

\begin{abstract}
In this essay UK housing is characterised by a marked cyclical volatility, unhelpful secular trends and unwillingness by successive governments to tackle key underlying policy constraints. The credit crisis and subsequent recession came at the end of a long boom in the UK housing market where affordability problems and other pressures were already established. There was a considerable market downturn but it was as much about reductions in volumes and related asset prices (land) as it was concerned with falling house prices and rents.

The threat of a much larger market downturn was an important element to the then Labour Government's expansionary response. Recovery under the following Coalition Government was patchy, slow in bedding-in and did nothing to address longer-term issues like access to home ownership, housing affordability or tackling a chronic shortage of new housing. Instead the $U K$ saw a large increase in private renting. Government responded in a range of ways, sharply reducing capital programmes for social housing, and radically restructuring welfare benefits, while other interventions supported mortgage borrowing and private renting investment. Both Scottish and Northern Irish devolved governments attempted to mitigate or prevent aspects of the welfare reforms.

This paper defends the need to apply long term policies to reduce market volatility and restore affordability and adequate levels of new housing supply. But genuine consensus is needed if the required policies are to be allowed to have the two full parliamentary terms required if they are to to be properly developed and implemented.
\end{abstract}

Keywords: housing market, housing policy, affordability, austerity, UK.

JEL classification: E61, E65, R20, R28.

\section{Resumen}

El mercado residencial británico se caracteriza por una remarcada volatilidad cíclica, por tendencias seculares inútiles y la falta de voluntad de los sucesivos gobiernos para hacer frente a las principales limitaciones políticas subyacentes. La crisis de crédito y la subsiguiente recesión ocurrieron al final de un largo boom en los mercados residenciales del Reino Unido, que ya contaban con problemas de accesibilidad y otras presiones, ajustando a la baja la edificación y el precio del suelo, pero no los de las viviendas y alquileres. La amenaza de una mayor desaceleración en el mercado fue un elemento importante a la respuesta expansiva del entonces gobierno laborista. La recuperación fue irregular, lenta en su aplicación y no hizo nada para abordar cuestiones de largo plazo como el acceso a la propiedad, la accesibilidad residencial o una escasez crónica de viviendas nuevas. En cambio, el Reino Unido experimentó un fuerte incremento en los alquileres privados. El gobierno respondió de diferentes formas, reduciendo los presupuestos para los programas de inversión en las viviendas sociales y para la propiedad, a la vez que se potenciaba la inversión privada para alquiler. A pesar de los intentos de mitigar los efectos que se hicieron en los gobiernos de Escocia e Irlanda del Norte, las políticas continúan teniendo el mismo signo. 
Este artículo defiende la necesidad de aplicar políticas de largo plazo que reduzcan la volatilidad y recupere niveles convenientes de accesibilidad y oferta de viviendas. Se necesita, para ello, consenso y dos legislaturas completas si se quiere que tengan una verdadera oportunidad de desarrollar adecuadamente esta política y hacerla funcionar.

Palabras clave: mercado residencial, política de viviendas, accesibilidad, austeridad, UK.

Clasificacion JEL: E61, E65, R20, R28.

\section{Introduction}

The UK housing market may reasonably be described in shorthand as possessing the following long-term characteristics. It has a large owner-occupied market, mainly funded by bank-originating mortgage finance. New housing supply is inelastic even in the long run. Rental housing is roughly evenly split between non-profit social housing and a resurgent though still small private rental market. The State intervenes extensively in the housing system, primarily through regulation and different forms of targeted subsidy, as well as means-tested benefits (Whitehead, 2002). The widely held assumption is that housing is unaffordable (particularly for first time buyers and for people in London and the South East but also elsewhere) and in endemic shortage. This is reflected in high house prices, rising rents and in particular marked volatility in terms of house prices oscillations in real and even nominal values (Barker, 2014). Housing is a key personal sector asset and is thought to play a significant role in macroeconomic debt, consumption and borrowing, including for non-housing equity withdrawal (Meen, 2003; 2006). There are major regional variations in housing costs and these are thought to impede mobility (O'Sullivan and Gibb, 2012).

This is a picture that many would recognise thinking about housing in 2015 . Arguably, it was also the scenario immediately prior to the financial convulsions that began in 2007. Going further back most of it would be recognisable to commentators looking at earlier boom-bust periods, such as the late 1980s and early 1990s (Maclennan and Gibb, 1993). One major indicator is UK house price volatility and their repeated cycling nature, as captured in Figure 1 (especially by the real price index). Although the focus of this paper is the UK housing sector response to the post-2007 crisis, a central theme is that the crisis was exacerbated by a set of chronic and still unresolved housing system features which continue to beset the performance of UK housing and impact more widely on the economy.

The period in question can be divided as follows. First, the crisis itself leading to housing sector impacts (reinforced by recession and slow economic recovery), followed by a series of housing and housing-related measures (which can be divided between successive UK governments around the 2010 General Election) and, finally, a period of housing market recovery (strongly regionally-pronounced).

Policy responses during this period can also be categorised into different clusters. First, there were policies aimed at mitigating the downturn, protecting households, shoring up institutions and explicitly trying to reduce subsequent falls in house prices. Second, there were, generally later, a series of market stimulus policies 
FIGURE 1

NOMINAL (DISCONTINUED) AND REAL HOUSE PRICES, UK, 1975-2015

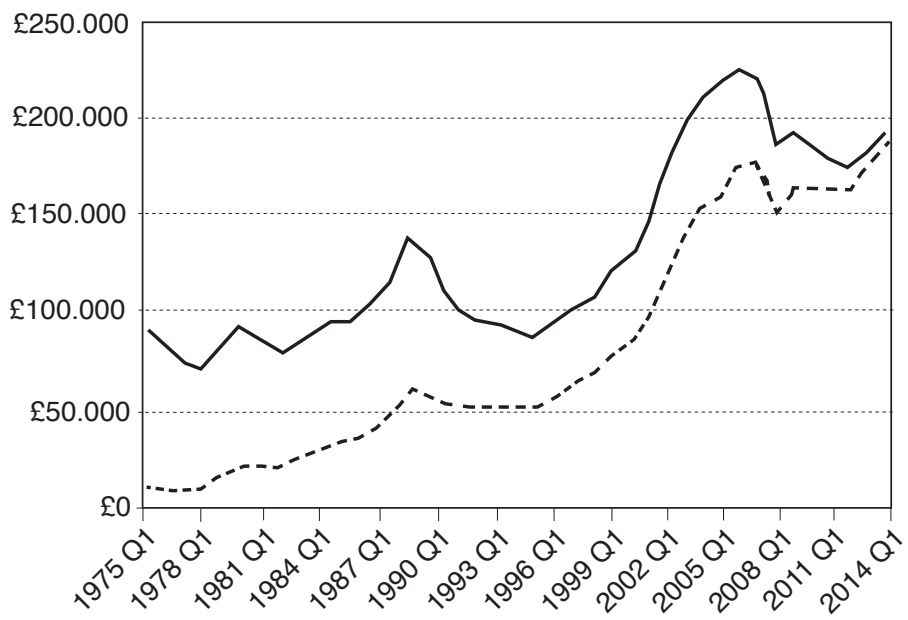

NOTE: House prices-UK all properties first quarter each year, not seasonally adjusted; real series are same prices adjusted for ONS RPI. Real price series at 2015 (Q3) prices.

SOURCE: Nationwide House Price Index (historical series).

aimed at specific, favoured parts of the housing system. Third, major policy reforms following the election of the Coalition government in 2010 led to radical reform of key ancillary policy areas - town planning ('localism') and welfare reform being the most significant. There were also major changes to social housing policy in this period, which are on-going but are likely to have a long term impact on-market provision.

The paper is a critical policy review structured around a number of themes. The first of these is the aforementioned inability to tackle long term chronic problems. Second, there is a sense of short termism and also a highly partial and un-joined up approach to housing belying the failure of successive governments to think of it as a system. Third, there are consequently important policy areas that need reform: mortgage/housing finance; housing and land supply; tax and subsidy reform, including low income personal subsidy; and, critically, an explicit policy aim of reducing volatility and stabilising real house prices. A more coherent policy framework would set a series of mutually reinforcing goals that seeks to overcome these problems over time and reduce the British obsession with housing by normalising it as both a consumption and investment activity (O'Sullivan and Gibb, 2012). This is a long term, redistributive and undoubtedly challenging programme (there will be short term losers) but it would greatly benefit the economy, society and the housing system. 
In public attitudes studies and in the media - housing is an increasingly important concern. Pressure for action is building.

Below, we consider the chronological narrative through a number of key stages that constitute the remaining sections of the paper. First, what did housing and policy for housing in the UK look like on the eve of the crisis? Second, what have been the major changes that have occurred subsequently and what do they mean for the attainment of a consistent holistic housing policy (as outlined above and described in more detail below)? Third, what has (permanently?) changed as a result of the GFC and its aftermath? Fourth, in the autumn of 2015, where does housing policy stand in the UK and to what extent is housing now nearer or closer to a more reasoned and sustainable approach to holistic housing policies for the future?

\section{The eve of the crisis}

There are different dates posited for the beginning of the crisis though the credit crunch began in Europe in the second half of 2007 along with the run on Northern Rock $^{1}$ in the UK. If we think about the housing sector on the eve of the crisis, data from 2006 and the half decade before would seem to be wholly appropriate (O’Sullivan and Gibb, 2008).

UK house prices were enjoying more than a decade of continuous increases, real interest rates were low, public expenditure had been increasing every year since 1999 and broader economic aggregates were well-behaved (real GDP growth varied from 2.4 to $4.3 \%$ between 2001-2007, inflation was never more than $4.3 \%$ in the same period, and interest rates fluctuated between 3.7 and 5.5\% [Wilcox et al., 2015, Table 1]).

However, there were dissenters pointing to growing imbalances in the economy. Much of the growth of the years in the run-up to 2007 was attributed to over reliance on debt-fuelled consumption and concerns were being voiced in some quarters about the financialisation of the economy within a context of consensual deregulation of the city and banking ${ }^{2}$. The scale of mortgage debt and the funding of that debt was a critical part of this debate. There were also heterodox economists like Steve Keen (2008) predicting big problems because of excessive private debt but they were only peripheral to these debates until it was too late.

\footnotetext{
${ }^{1}$ A major UK mortgage lender that collapsed in 2007 following the largest run on a UK bank for more than a 100 years.

${ }^{2}$ One leading politician [and economist], Vince Cable of the Liberal Democrats, wrote a much quoted book on the crisis ('THE STORM', 2009) making many of these points. Subsequently, he was a senior cabinet minister for the UK coalition government.
} 
Meanwhile, there was plenty of evidence of problems building in the UK housing system. Sustained rising real house prices, regionally varied but particularly strong in the increasingly separate London and Home Counties markets, were also generating cumulative affordability and labour mobility problems (Wilcox et al., 2015). This was reflected in the rising average age of first time buyers, the rising absolute cost of down payments, higher loan to income ratios for first time buyers and, most tellingly, a slowing down and then decline in the share of households in home ownershiphome ownership peaked at $69 \%$ in England in 2002 but then fell back to less than $64 \%$ in 2012 (Wilcox et al., 2015, Table 17d). At the same time, private renting was starting to grow significantly as a consequence of the embedding of Buy to Let as a successful private sector model facilitating small scale investor activity.

There was also plenty of evidence that the primary residence mortgage market had matured and growth areas had shifted to re-mortgaging (enticing mortgagors to switch providers and find better deals) in order to increase market share and also the aforementioned Buy to Let market (the BTL market grew by more than five-fold to just over a million outstanding loans in 2007 - Wilcox et al., 2015, Table 55). And, there was strong pro-cyclical housing equity withdrawal underway as home owners cashed in on paper increases in property value by borrowing for non-housing consumption reasons (equity withdrawal peaked at a little less than $8 \%$ of consumer spending in 2003 - Wilcox et al., 2015, Table 7). On a comparatively small-scale, mortgage lenders were engaging in sub-prime lending [Stephens and Quilgar, 2008] but we should not equate this with the depth of US securitisation and NINJA style loans. Probably more significant was the increasing reliance on wholesale funding (short term inter-bank lending) and investment in US sub -prime mortgage derivatives, which along with excessive lending would cause such problems for Northern Rock. The Government also initiated a review of mortgage market funding led by David Miles (Miles, 2004).

In the early 2000s, the UK Government lunched comprehensive reviews of housing supply as well as a subsequent review of land and planning, both led by Kate Barker (Barker, 2004, 2006, 2014). This reflected growing concerns about the long term consequences of cumulative real house price increases well above the European average and whether it was possible to make significant and permanent increases to the long run price elasticity of supply. Key elements to the solution were believed to be: better evidence on housing markets to inform key actors, more responsive land supply and better incentives to use land for housing, encouraging reform to the private development sector and supporting major new communities. During this period one important use of the planning system had been to extract planning gain from larger developments in the form of contributions to affordable housing supply (Burgess et al., 2011). This cross subsidy led to the building of many tens of thousands of housing association units in mixed tenure sites that fundamentally changed the geography of their location (Meen et al., 2005). 
Policy makers and commentators were not unaware of the evidence of these different chronic problems but were neither obliged to nor did they prioritise housing for reform. There was undeniably a degree of complacency or at least that these questions were too difficult politically (that is, too many vocal losers from reform). That is not to say that there were not important interventions affecting the housing sector. The UK government was exploring reform of housing benefit to make it more of an ex ante allowance though this was only actually introduced in the private rental sector. The Government also began several years of varying the stamp duty provisions taxing property sales in order to incentivise investment in specific places as a form of regeneration policy (later, in the downturn, cuts in stamp duty were used to try to help sustain market transactions).

Major constitutional devolution took place in 1999 and aspects of housing policy were devolved to sub-national (relative to the UK) governments. However, there is scant evidence that the devolved administrations were better placed to overcome the political economy problems of housing policy reform. In 2007, the new Scottish National Party government launched an ambitious green paper on housing policy (Firm Foundations). Much of this ambition was blown away by the financial hurricane that followed but it did include the proposed outlawing of the Right to Buy for tenants living in new properties. In time this enabled councils in Scotland to start once again building social housing and this would turn out to be a useful adjunct to housing policy in Scotland (later all right to buy sales would be abolished) and one quite contrary to the thrust of policy in England. Nonetheless, the broader point, of a degree of awareness about chronic problems but an unwillingness to prioritise in the face of worsening indicators as 2007-08 approached, would be a sober summary of where things stood across the UK as the financial crisis arrived.

\section{The major changes wrought}

The UK housing sector entered a major downturn initially as a result of the housing finance credit crunch in 2007-08 but this became a 'real' phenomenon as the housing sector contributed thereafter to a general recession and slow uneven recovery. The housing market as a whole did not show consistent signs of recovery in terms of prices, starts market activity and lending till 2012, or in some cases, 2013 (Wilcox et al., 2015). Some of the more disadvantaged local and regional economy housing markets remain weak. Indeed, in Northern Ireland, where the housing market had the most extreme boom and bust, the growth indicators were only in 2013-14 showing any sustained evidence of recovery (Wilcox et al., 2015, Table 47a). Analysis reported by CHMA (2015) suggests that outside of London, house prices in the rest of the UK are now not far from their 2007-08 pre-crisis peak but London has now raced well above that threshold.

Arguably, unlike the previous market down turn (1989-92), the 2008-13 UK 
housing sector was not as characterised by large nominal price falls, negative equity, large increase in arrears turning into defaults (and repossessions by lenders). These things happened but not so dramatically for reasons we will explore later in the paper. There were sustained house price falls but they were shallower and in some places of shorter duration (e.g. London) but the striking feature was the big falls on key volumes: housing transactions, mortgage lending, new supply and land prices [Gibb and O'Sullivan, 2010; Gibb, 2015; Wilcox et al., 2015]. Gibb and O'Sullivan reported that in 2008 alone, transactions fell by $46 \%$, lending by $57-59 \%$, new starts fell by $47 \%$ and land prices dropped by $48-49 \%$ (Table 1, p.98).

While house prices did fall, bottom out and then start to increase again, private rents held up but did not do much better than admittedly weak inflation during the period. Meanwhile estimates for land prices showed huge falls, clearly relating to investors pessimism about the future, the declining capacity of housing developers and the rapidly declining availability of bank finance for home lending and development finance.

The key to this was the withdrawal of lending. In 2007 mortgage lenders were providing new loans (gross advances) to the value of $£ 363$ billion. Lending thereafter fell sharply as they sought to repair their balance sheets and reprice existing loans (Wilcox et al., 2015). In particular, the repricing of loans required higher deposits and lower loan to income ratios and closer credit checks. This conservative turn in lending in the context of an emerging recession and pre-existing affordability concerns for would-be buyers, significantly reduced demand for housing. Bank lending also dried up in terms of the critical role it played in social housing finance (discussed further below). The overall level of (second hand and new) housing transactions fell massively with negative multiplier effects on the rest of the economy (Gibb et al., 2013).

The most devastating effects were felt by the predominantly volume housebuilding industry that saw a large scale reduction in housing completions, a trend only turning round significantly by 2014 . Much capacity has been lost and in recovery the sector has been slow to ramp-up new build (Wilcox et al., 2015). Instead it has tended to build in phases only in sufficient numbers to meet demand (Payne, 2015). The sector remains a long way from its speculative zenith prior to the crisis.

Despite this significant shock to the housing system, and with substantially increased levels of arrears and repossessions compared to the pre-crisis period, repossessions in a now much larger mortgage market, peaked in 2009 at less than 49,000 compared to the previous high of more than 70,000 in 1992 (CHMA, 2015; Wilcox et al., 2015). This is partly lender response, partly also the impact of government policies that sought to minimise default not just for social reasons but in the belief that they would exacerbate price falls and deepen recession.

The recession took the form of a sustained drop in output and economic activity followed by a lengthy flat and faltering recovery - an L-shaped response to recession with GDP growth not exceeding 2\% till from 2008-13 inclusive (Wilcox et al., 2015). There is much controversy as to whether and to what extent the post-2010 Government's economic policy of deficit reduction (austerity) lengthened the 
stuttering recovery period or was in fact a price worth paying for longer term fiscal strengthening ${ }^{3}$. Nonetheless, it was widely recognised that the housing sector's troubles were contributing to the economic malaise. Much was written about the role of housing in the economy on both the aggregate demand and aggregate supply sides as a result of the last major boom and bust and this arguably did play a role in the thinking of particularly the New Labour government that was in power till 2010.

Consumers respond to the housing market downturn and the loss of economic confidence often by speeding up debt repayment, reducing consumer spending and cutting back on borrowing - the classic liquidity trap problems when very low interest rate apply in a depressed economy. Housing equity withdrawal went into reverse and became negative for the entire period 2008-13, undoubtedly slowing down the consumption path out of economic stagnation (Wilcox et al., 2015). Increasing housing activity and particularly house prices has been a strong though often implicit part of Treasury policy for the economy under both the UK Coalition and now Conservative governments.

How did the different UK governments respond? Labour (2007-10) operated in the eye of the crisis and then in response to recession. The key measures involved:

- Guaranteeing the banks as a whole and providing specific guarantees to encourage banks to show forbearance to clients in mortgage arrears (offering to pay back a portion of losses after 2 years)

- Nationalising key banks to stop them failing and attempting to insulate the rest of the system from them: Northern Rock, HBOS, Lloyds and RBS among others were all taken over or in some way part-nationalised, but Government also played an explicit or implicit role to restructure the industry through mergers, sales and other actions.

- Beginning in 2009, developing the quantitative easing or expansionary monetary policy model for the UK based on the US approach - buying bonds in order to inject cash onto the system.

- Reintroducing a more comprehensive system of social security to help home owners who qualify for income support - more generous and timely than the existing system ${ }^{4}$.

- The counter-cyclical use of stamp duty rates and exemptions to try to help stimulate the housing market.

The Coalition Government (Conservatives and Liberal Democrats) was elected in the summer of 2010 and characterised itself as a deficit-reducing government with the core aim of 'repairing' the economy. It went about this by:

\footnotetext{
${ }^{3}$ A lively and always interesting website blog by Simon Wren-Lewis, Mainly Macro, covers this topic extensively - http://mainlymacro.blogspot.co.uk.

${ }^{4}$ This is now coming to an end and being replaced with loan-based products that will revert to the earlier 39 weeks before eligibility begins.
} 
- Making large cuts inter alia to social and affordable housing spending (replacing the old mixed finance system of grants and private loans with a new supply programme for housing associations based on lower grant, high rents and 'subsidy' from higher rents imposed on vacant properties [Gibb et al., 2013]).

- Swingeing (and ongoing cuts to housing benefit), first to the private rented sector and then to all working age tenants, as a precursor to the introduction of Universal Credit which intends to bring together 5 working age benefits and tax credits into a single taper benefit (Gibb, 2014).

- A series of other housing-specific policies were developed including within wider 'localism' reforms to the planning systems (e.g. doing away with regional planning in England) a shifting of the assumptions to S106 planning agreements which in practice made it harder for social and affordable housing to be the outcome (Wong et al., 2011).

- Other policies to promote private renting supply with the state for instance acting as an equity partner by providing repayable loans.

- Loan guarantees to reduce the cost of borrowing for housing associations (also in part to support lending to the private rented sector).

- Various policies to stimulate home ownership, shared ownership and shared equity products as well as guarantees to encourage lending (Help to Buy products both for first time buyers and the general market) and re-encouraging the Right to Buy (in England).

Not all policy developments pivoted around a sharp break in 2010. Both governments supported and enabled the re-regulation of the mortgage market (the Mortgage Market Review) ${ }^{5}$ and this has led to a number of specific reforms to lending practices, the nature of the relationship between lender and borrower and in terms of regulatory oversight powers. It remains to be seen whether this will be sufficient or an appropriate regulatory burden, as it will require evidence over a full market cycle to judge (Housing and Wellbeing Commission, 2015).

Perhaps the other most striking feature of the post 2007 housing policy context has been the sub-national divergence in policy responses (Gibb, 2015). Since 2007, the Scottish government has always been a different political colour from the UK government (Scottish nationalists held a minority government 2007-11 and a majority 2011-16), an all party coalition has led Northern Ireland's government throughout and Wales has never had the Conservative party in government. This has led to important policy distinctions, particularly since 2010 . However, housing policy is a hybrid - mainly devolved but still with important elements reserved (Gibb, 2012, 2015). It has been at the margins of the latter, e.g. housing-related welfare benefits, which has been particularly disputed by Edinburgh and Belfast relative to the UK government position. Through the Barnett Formula that allocates funding at the margin across the

\footnotetext{
${ }^{5}$ See Financial Conduct Authority 2015: http://www.fca.org.uk/firms/firm-types/mortgage-brokers-andhome-finance-lenders/mortgage-market-review.
} 
UK, devolved governments have also seen their budgets hit hard and reductions in spend have spread into housing programmes.

For example, the Scottish government has pursued separate social and affordable housing policies (Gibb, 2015). They have abandoned the right to buy, encouraged new partnerships between councils and the private sector to build affordable housing, chosen to increase grant rates rather than significantly reduce them (though with a constrained overall programme for affordable supply), they have used public funds to mitigate benefit cuts (the Bedroom Tax and cuts to Council Tax Benefit) and, currently, they are consulting on legislation to reintroduce elements of regulation including scope for rent increase limitations in the private rented sector (in designated pressured local markets).

\section{What has been changed permanently?}

Dealing with a highly cyclical sector such as UK housing one should be reluctant to make claims that impacts such as those discussed above generate permanent changes to behaviour, processes and policy. It is also early to make such a claim. And it is striking how much remains the same in spite of the hard lessons for housing actors and for those responsible for housing policy. Path dependency (and an element of mean reversion in the market), plus the perceived high cost of making the long term changes that will bring about a more desirable normative housing policy framework (as introduced earlier) combine to inhibit long term reform.

What is apparent is that several previously important policy levers may have been removed at least for the foreseeable future and also there are discernible trends in the housing system, which are themselves indicative of new challenges. It is against this emergent set of possibilities that we need to consider where the direction of current housing policy appears to be heading.

Important housing and housing-related interventions that have been significantly altered include first UK welfare reform, reducing housing benefit support for working age households (e.g. reductions in the absolute amount of support to private tenants, caps on overall household housing benefit levels, caps also on the uprating of housing benefit annually, reduction in HB for those with spare rooms and reduced support for younger single people [Gibb, 2014] $)^{6}$. English planning agreements (S106 of the relevant legislation) to support and cross-subsidise social and affordable housing, have been altered first by introducing a viability clause that makes the imposition of affordable homes more challengeable by private developers; second, by encouraging its use for specifically private rented housing and, now, third, as part of emerging

${ }^{6}$ As a result of subsequent constitutional legislation currently in the UK Parliament and following the 2014 independence referendum, the Scottish Parliament will have additional powers to vary housing elements of the Universal Credit when it is introduced, as well as powers to top up (and to pay for) existing benefits. 
policy to promote discounted first time buyer homes within larger new private housing developments.

From 1988-2008, the dominant way of funding new social housing (the mixed finance regime) involved a fixed level of grant alongside private finance to meet the remaining costs of development and paid for from (affordable) rents. Over this period, the system came under considerable strain as overall programme size varied and average grant per unit fell. Increasingly other resources met the emerging gap (searching out cheaper sources of finance, S106 contributions, cross-subsidy from sales on mixed tenure developments, as well as equity contributions from reserves and previous annual surpluses). However, the model unquestionably relies on both the willingness of lenders to make long-term finance available (this became much less available after 2008) and for a strong private market to generate the sales for cross subsidy and S106 agreements (even before the policy stance changed). Thus, the ability of the mixed finance system to ride out economic difficulties was undermined and, so far, no obvious alternate sustainable model has emerged in its place. The UK Coalition government did deliver a large affordable supply programme in England based on much lower grant rates delivered by housing associations and it relied heavily on significantly higher, but still sub market, rents ${ }^{7}$ - including using higher rents associated with refilling void units among the developer's existing housing stock (and often relied in practice on local S106 agreements as well) (Gibb et al., 2013).

Regarding the possible long term trends that are likely to outlast the current cycle -the first is the relative and absolute growth of the private rented sector. Part of its remarkable growth is constraint-based and due essentially to lack of access to affordable home ownership but arguably it is also increasingly about preference and wider choice rental opportunities, particularly in cities and in follow-on housing for graduates (Scanlon et al., 2013). However, it should be acknowledged that home ownership may be more affordable in the future and also the largely atomised landlord sector could well be negatively affected by recently announced tax changes (i.e. higher rate tax relief on lending for business purposes for private landlords is to be withdrawn and, as a result of the Autumn Statement by the Chancellor in November 2015, stamp duty land tax is being raised by $3 \%$ at all levels for sales of second homes and investment properties). This recent reversal has been rationalised as government responding to Bank of England worried about bubbles in buy to let investment but these tax-based policies do not seem to be the most targeted means of intervening in the sector.

A second key area is the private development sector. Homebuilders endured a significant and sustained reduction in demand and though output levels are now rising, the evidence continues to suggest that their business model (Lyons, 2014; Payne, 2015) is now much more about cost control and building out to levels of

${ }^{7}$ Typically $65-85 \%$ of the relevant median private rent in the area with lower $\%$ rents found in higher demand areas. 
demand on specific sites only and not pushing forward more speculatively with new supply. This will not generate the levels of completions that government and housing lobbies are suggesting to meet demographic and unmet housing needs (Payne, 2015). Of course, this may be a slow transition back to earlier business norms. A similar tension hangs over lending for housing - there is now more regulation of mortgage lending including from a macro perspective by the Bank of England - but it is not clear whether in the longer term this will prove to be the appropriate level both macro-prudentially and in terms of market impacts.

A further apparent break from the past may also be important. The newly elected majority Conservative government has responsibility for housing policy in England as well as various fiscal and monetary policies that affect the housing sector across the UK. The Government has announced a series of far-reaching proposals for social housing. These will further differentiate England from the rest of the UK and call into question the continued existence of housing associations in their current format in England. The plans include:

- The introduction of a negotiated discounted sale to sitting tenants of housing associations across England with replacement social properties to be funded by councils selling-off their high value properties to pay for it ${ }^{8}$.

- The likely removal for all intents and purposes of grant to support the subsidised development of social housing 9 .

- The introduction of market rents for high income tenants in social housing.

- The end of life time tenancies for tenants of social housing.

- The Budget decision to impose rent reductions on social housing in England (in order to reduce the housing benefit bill) for the next four years.

Finally, in late October 2015, the Office of National Statistics, on the basis of legislation in 2008 (i.e. by a Labour government) that increased regulatory powers over housing associations in England, decided to reclassify housing associations as public non-financial corporations, essentially adding their entire debt (more than $£ 60$ b) to the public national debt ${ }^{10}$ and implying a substantial degree of HM Treasury control over new borrowing. This classification change from the private sector, based on European accounting conventions and the extent to which the sector is controlled by the State, may or may not have important long-term consequences. What we know is that the UK government is planning legislation, which it hopes will reverse the re-classification process by in some way deregulating the sector ${ }^{11}$. Credit rating

\footnotetext{
${ }^{8}$ English housing associations agreed to a voluntary policy on RTB - in the mistaken belief that this might head off reclassification of the sector into the public sector, which it turned out happened anyway.

9 This, along with other key public funding decisions across government will be announced in the Treasury's five year spending review in late November 2015.

10 This only applies in England.

11 Most recently, in December 2015, the UK government has announced that participating associations can volunteer into or opt out of the new discounted sales scheme. In part, this is presumed to strengthen the deregulation case and support re-classification. There may also be further revisions to the direction of housing policy in England to follow.
} 
agencies have said lenders may view the reclassification legitimately as a major event triggering their ability to reprice their existing loan book with housing associations, as part of the terms of their loan covenants. Clearly, the proposals set out above by the new government are further controlling measures which may reinforce this new classification (and which deregulation will now seek to reverse). The experience of government policy surrounding English housing associations in recent years thus exemplifies, at best, a remarkable degree of policy incoherence.

\section{Are we now closer to or as far away from a coherent policy?}

Where stands UK housing policy now? It is difficult to make a case that housing policy is now more coherent, sustainable or systemic in outlook than it was prior to the financial crisis. At the beginning of the paper a number of themes were identified. The first is the inability and electoral unwillingness over several successive Governments to tackle long term chronic problems. Second, much policy is characterised by an underlying short termism, incoherence and also a non-systemic approach to housing. Third, there are clusters of policy problems that urgently need to be addressed (mortgage/housing finance; housing and land supply; tax and subsidy reform; and, the aim of stabilising real house prices).

Housing is a long-lived asset and adjustment to equilibrium and indeed the ability to respond to non-trivial policy initiatives takes a long time. It is absolutely essential therefore that consensus-based approaches are used to break through the impediments hindering the attainment of agreed long-term policy reforms. A growing list of independent inquiries about housing failure, unaffordability, shortage and wellbeing are a helpful contribution to take us beyond narrow and often ideologically motivated think tank promulgations (e.g. RICS Scotland, 2014; Housing and Wellbeing Commission, 2015). The building of a reform vision around a consensus set of key aims is essential and is a pre-condition for cross party agreement on a programme of reforms that will need to be sustained over two or more Parliaments (at least a decade). Governments must adopt a systemic cross-departmental approach that is preventative (i.e. there will be long term savings and benefits to productivity and social justice) and invest as much in evidence-gathering, implementation and monitoring, as they would in designing the programme. This is massively challenging for the UK political elites and unfortunately seems far removed from typical time horizons or interest in the future relative to the present. But overcoming these structural, agency and systemic policy failures is essential to converting the priority level of housing in current public attitudes and media discussion into real purposeful action (King and Crewe, 2013; Shuck, 2013; Gibb, 2014).

Presently, however, government seems to be more concerned with maintaining rising real house prices, making claims about increasing private housing supply (but is unable to demonstrate how to achieve and sustain the levels of completions required), delivering contradictory signals to the private rented sector (cutting tax 
reliefs and increasing stamp duty but elsewhere promoting the sector) and now launching multiple attacks on social and affordable housing such as the proposed cuts in rents that threaten operational budgets and long term investment planning across the housing association sector. ${ }^{12}$

The key role of housing benefit reform and its role underwriting private finance in social housing and the growth of the lower end of the private rented sector is an interesting example of the paradoxes and political no-go areas that emerge in response to political and economic crisis. Years before the financial crisis, New Labour was put under (self-inflicted) pressure to support the raising of incomes for pensioners in the UK and this over time locked-in ongoing support to counter pensioner poverty, something retained by succeeding governments as something of a red line issue (Adams et al., 2012). Welfare spending cuts have therefore been exclusively focused on working age households and families. This has had some bizarre impacts: most under-occupation in the UK is found among home owners and by retirees -yet the so-called bedroom tax is exclusively focused on a small minority of under-occupiers in the working age social renting category (most of whom appear to be disabled or facing long term illness) (Clarke et al., 2014; Gibb, 2015).

The short run picture is not encouraging. But taking a longer view real change is possible. There are growing concerns about inter-generational inequality related to housing market failure in the UK as well as due to the lock out of younger households from home ownership. The large scale of poverty in the form of food bank demand, in-work poverty and insecurity continues to support demand for low cost good quality rented housing (Housing and Wellbeing Commission, 2015). In Britain, in the not too distant past it was possible to eliminate 'bad' subsidies (mortgage interest tax relief), build consensus around long term policies (homelessness in Scotland) and produce systems approaches to housing planning at metropolitan scales. There is policy experimentation on the ground and there is a desire to do something progressive and lasting about a sector as important and connected to wellbeing as housing clearly is, be it in terms of improving our places, communities and the lot of different socio-economic groups.

While housing is increasingly prominent among newspaper columnists and is evidently rising up political party agendas, simply convincing more of the UK's political elites to recognise the folly of volatile and rising house prices for succeeding generations and for labour mobility reasons, would be a major inroad. Thinking constructively also about tax instruments, better-designed subsidy to housing and policies to unlock supply and make housing finance work more effectively for the housing system as a whole - would be key building blocks to normalising the housing sector and letting people get on with their lives.

\footnotetext{
${ }^{12}$ See Inside Housing news website: http://www.insidehousing.co.uk.
} 


\section{Conclusions}

Housing in the UK has been through a prolonged and painful cycle of unsustainable boom, bust and slow recovery. But even more important, it is at the mercy of long term trends and the inability and unwillingness of successive governments to address the underlying sources - long term rising real prices, ineffective tax and subsidy systems, housing finance, permanently increasing weak supply elasticity and overall, the inability to conceptualise and operationalise let alone implement, policies that would enable housing system balance. Worse, however, the response to the downturn (especially post 2010) has been to pursue a series of short term policies sometimes in contradiction to other parts of the housing sector, alongside spillovers from welfare and tax reform.

We seem to have retreated from any considered efforts to produce systemic polices for the sector as a whole that focus on efficiency and equity goals. Instead, the UK has returned to an era where narrow, politicised goals of policy (e.g. increasing home ownership and reducing public spending on social housing) and the setting of public targets/aspirations (e.g. for building homes) are pursued with insufficient thought for implementation, or whether the policy can ultimately be achieved or to the unintended consequences and general equilibrium second round impacts of such policies.

\section{What is going on?}

Home ownership and the protection of owner asset values seem to be politically inviolable. Yet at the same time, resilient good husbanding of organisations in the long term interests of tenants by housing associations is seen as wasteful and hoarding scarce resources. A climate is created whereby the government would rather support discounted entry-level home ownership through planning agreements than target resources where need is highest. This largely unquestioned maintenance of the interests of insider home-owners is at the expense of outsider future owners and tenants who face higher entry barriers to owning and escalating private rents (as well as higher land prices for all). The electoral fears about alienating home-owners evident across a large body of like minded people is easy to understand but operates within a political mind-set that includes the ideas that we 'must fix' the public deficit for the long run and 'must protect' pensioner financial interests permanently. It remains faintly incredible that we cannot also start to take the required medicine to make the housing market more neutral, less exclusive and more accessible for the many.

Conservatism in the media, the political classes and the commentariat are all part of the problem - that is why the recent uptick in broader and more holistic housing policy commissions saying what needs to be said is to be welcomed as an important contribution. But the argument needs to be made across several dimensions: 
- Housing is an immobile asset of extensive taxable potential, which, if more effectively used, could widen the overall tax base and reduce upward pressure on marginal tax rates on more productive and mobile areas like income tax.

- Stable real house prices and rents would support economic planning as well as individual decision making about saving, investments and portfolio choices in more productive areas of investment. It will also reduce cost induced pressure on housing benefit.

- A tenure-neutral as well as an investment/tax neutral system would reduce unintended consequences and unwanted spillovers (Mirrlees, 2011).

- Can the outcomes of the land use planning system be changed, particularly reducing the returns associated with receiving planning permission (along with active support for SME builders)? While not supporting price controls, a much more active role by the public sector via a national land development agency could play a constructive role by using its market power creatively. Equally, we may want to consider fundamental land use reform that works more with the grain of the market (Cheshire, 2014).

- Rather than try to find ways to encourage institutions to invest in private renting -can the funds instead play a more useful role in both the home ownership sector and social housing- matching long term assets to liabilities in a way more suited to their interests than 'lending-long, borrowing-short' banks (Goodhart and Perotti, 2015)?

We need a broader alliance of civic society (including opinion formers in the media, social media and think tanks) to force government and opposition (and devolved governments) to establish a comprehensive long term policy reform commission tasked with delivering a phased legislative programme of cumulative reforms that will move the housing sector over time in the right direction and that will damp transition and where genuinely required provide compensation to potential losers. We also need to find effective ways to motivate and incentivise politicians to change from their short run (next election myopia) obsessions by establishing real consensus about meaningful change. This is undoubtedly highly challenging and ambitious. I am sure many will view such thinking naïve but the cost of not doing so, of letting the status quo continue and with it the dog's breakfast of policies, knock-on inefficiencies and the abject failure to address the long term blockages and poisons in the UK housing sector, is simply unacceptable. 


\section{References}

[1] ADAMS, S.; BROWNE, J. and JOHNSON, P. (2012). Pensioners and the Tax and Benefit System. IFS Briefing Note BN130. Institute of Fiscal Studies, London

[2] BARKER, K (2004). Review of Housing Supply. HM Treasury, London.

[3] BARKER, K. (2006). Review of Land Use Planning. HM Treasury, London

[4] BARKER, K. (2014). Housing: Where's the Plan? Publishing Partnership, London.

[5] BURGESS, G.; MONK, S . and WHITEHEAD, C (2011). «Delivering local infrastructure and affordable housing through the planning system: the future of planning obligations through Section 106». People, Place and Policy Online, 5 (1), 1-11.

[6] CHESHIRE, P (2014). «Turning Houses into Gold: the Failure of British Planning. LSE Online/CEPR».http://blogs.lse.ac.uk/politicsandpolicy/turning-houses-into-gold-thefailure-of-british-planning/.

[7] CHMA (2015). Scottish Housing Market Review. Centre for Housing Market Analysis, Scottish Government, Edinburgh.

[8] CLARKE, A.; HILL, L.; MARSHALL, B.; MONK, S.; PEREIRA, I.; THOMSON, E. and WILLIAMS, P. (2014). Evaluation of removal of the spare room subsidy: Interim report. London, DWP.

[9] GIBB, K. (2012). «Is Scottish housing policy diverging from policy in England? The complexity of devolution in practice». Housing Finance International, 26 (4), 21-26.

[10] GIBB, K (2015). «The Multiple Failures of the UK Bedroom Tax». International Journal of Housing Policy, forthcoming, vol. 15.

[11] GIBB, K (2015). «Housing Policy in Scotland since Devolution: Divergence, Crisis, Integration and Opportunity». Journal of Poverty and Social Justice, vol. 23: Online ISSN 1759 8281. http://dx.doi.org/10.1332/175982715X14229585605431.

[12] GIBB, K.; MACLENNAN, D. and STEPHENS, M. (2013). Innovative Financing of Affordable Housing: International and UK Perspectives. Policy Press. Bristol.

[13] GIBB, K. and O'SULLIVAN, A. (2010). «Housing-led Regeneration and the Local Impacts of the Credit Crunch». Local Economy, vol. 25, 94-107.

[14] GOODHART, C. and PEROTTI, E (2015). «Keeping a roof on maturity mismatch on lending». Financial World, August/September, pp. 6-7.

[15] HOUSING AND WELLBEING COMMISSION (2015). A Blueprint for Scotland's Future. Shelter Scotland, Edinburgh.

[16] KEEN, S (2008). Debunking Economics. Zed Books, London.

[17] KING, A. and Crewe, I. (2013). The Blunders of our Governments. One World, London.

[18] LYONS, M. (2014). The Lyons Housing Review: Mobilising Across the Nation to Build the Homes our Children Need. http://www.yourbritain.org.uk/uploads/editor/files/The Lyons_Housing_Review_2.pdf.

[19] MACLENNAN, D. and GIBB, K. (eds.) (1993). Housing Finance and Subsidies in Britain. Aldershot, Avebury

[20] MEEN, G. (2002). «Housing, random walks, complexity and the macroeconomy», in T. O'Sullivan and K. Gibb (eds.), Housing Economics and Public Policy. London, Blackwell.

[21] MEEN, G. (2006). «Ten New Propositions in UK Housing Macroeconomics: An Overview of the First Years of the Century». Urban Studies, 45 (13), 2759-2781.

[22] MEEN, G.; GIBB, K.; GOODY, J.; MCGRATH, T. and MACKINNON. J. (2005). 
Economic Segregation in England: Causes, Consequences and Policy. Policy Press, Bristol.

[23] Miles, D. (2004). The UK Mortgage Market: Taking a Longer Term View. HMSO, London.

[24] MIRRLEES REVIEW TEAM (chaired by Sir James Mirrlees) (2011). Tax by Design. Oxford University Press, Oxford.

[25] O'SUlLIVAN, A. and GIBB, K. (eds.) (2002). Housing Economics and Public Policy. Oxford, Blackwell Science.

[26] O'SULLIVAN, A. and GIBB, K. (2008). The Credit Crunch and the Scottish Housing System. Chartered Institute of Housing (Scotland), Edinburgh.

[27] O'SULLIVAN, A. and GIBB, K. (2012). «Housing Taxation and the Economic Benefits of Home Ownership». Housing Studies, 27 (2), 267-79.

[28] PAYNE, S. (2015). «Examining the Supply challenges for British House Builders in the 'Post-Recession' era». Housing Studies Association conference, York, April.

[29] RICS SCOTLAND (2014). RICS Scotland Housing Commission - Building a Better Scotland. RICS, Edinburgh.

[30] SCANLON, K.; WHITEHEAD, C.; WILLIAMS, P. and GIBB, K (2013). Building the Rented Sector in Scotland. Homes for Scotland, Edinburgh

[31] SCHUCK, P. (2014). Why Government Fails So Often. Princeton, NJ: Princeton University Press.

[32] STEPHENS, M. and QUILGAR, D. (2008). «Sub-Prime Mortgage Lending in the UK». International Journal of Housing Policy, vol. 8, 197-215.

[33] WHITEHEAD, C. (2002). «The Economics of Social Housing», in A. O'Sullivan and K. Gibb (eds.), Housing Economics and Public Policy. Blackwell Science, Oxford.

[34] WILCOX, S.; PERRY, J. and WILLIAMS, P. (2015). UK Housing Review 2015. CIH, Coventry.

[35] WONG, C.; GIBB, K.; MCGREAL, S.; WEBB, B.; LEISHMAN, C.; BLAIR, N.; HINKS, S. and MACINTYRE, S. (2011). Housing and Neighbourhoods Monitor 2011: Fragile Recovery. Policy Press, Bristol. 